cantata was then given, and this brought the meeting to an end.

In the evening the King and Queen received all the delegates at the castle, and said a few gracious words to each guest.

On Wednesday (September 6) the second formal meeting took place in the handsome new Aula of the University. This hall is not so large as the National Theatre, where the meeting had taken place on the previous day, so that it was only possible to admit national and foreign delegates, but other entertainments were provided by the committee of ladies.

The proceedings on this occasion consisted of instrumental and vocal music, and of a short address by Prof. Stang on the work of the University. The rector then explained that in the honorary degrees which were to be conferred, the claims of mathematics and astronomy were purposely excluded, because degrees in these branches of science had been conferred only a few years ago, on the occasion of the Abel Festival, I myself having then received a degree.

The heads of faculties then presented the names of the several doctors in the various departments of learning to the rector. It may be interesting to note that of the five speeches two were in English, two in German, and one in French. The degrees were then conferred by the rector on the new doctors, of whom but few were actually present. It may here suffice to say that the new British doctors were Prof. Sanday, Prof. Alfred Marshall, Sir Frederick Pollock, Sir Thomas Barlow, Sir John Bradford, Sir William Osler, Prof. Sayce, Dr. Henry Sweet, Sir James Dewar, Principal Miers, Sir John Murray, Sir William Ramsay, Prof. Sollas, and Sir Joseph Thomson.

In the evening the Municipality of Christiania entertained the delegates at dinner in the municipal buildings.

On the following morning a number of parties were taken round the museums, and the two old Viking ships naturally attracted much attention. In the afternoon the Videnskabs Selskabet-the national academy of science-gave a party in the garden attached to their fine house. This home of science was presented to the society not long ago by two Norwegian ladies, whose names, unfortunately, I omitted to take down. As the weather was glorious, this was one of the pleasantest of our many entertainments.

In the afternoon Prof. Birkeland gave a lecture in French on the phenomena attending the discharge of electricity through rarefied gas, with the application of his ideas to cosmogony on the largest scale. The lecture was of great interest; but it contained so much that was new, at least to me, that I will not venture to give a detailed account of his results. I understand that he is now sending a paper on the subject to the Comptes rendus.

The festival at Christiania terminated with a brilliant gala performance at the theatre of three acts of Björnson's "Mary Stuart," in the presence of the King and Queen.

On the following morning (Friday, September 8) a large number of the delegates, accompanied by ladies and their Norwegian hosts, left Christiania for Bergen in a special train put at their disposal by the Government. The line affords scenery of great beauty, and is a monument of the triumph of the engineers over enormous difficulties, for we climbed to the height of 4000 feet, and reached the region of snow and glaciers. The weather had been magnificent on the eastern side of the mountains, but we were in heavy rain as we descended the wonderful gorges of the western side. It had been supposed by most of us that the arrival at Bergen would be the real end to the hospitality shown to us; but in this we were mistaken. Every house in Bergen was illuminated in our honour, so that we ran into a city of light, and, notwithstanding the heavy rain, the streets were densely crowded in the neighbourhood of the station. On Saturday and Sunday it was fine again, and thus we learned that Bergen is not a city of eternal rain.

On Saturday a visit to the museum and to the marine biological station had been organised, followed by a drive through the romantic hills which surround the town. In the late afternoon the municipality, as represented by the President and by the first Burgomaster (for in Norway there are two Mayors for each city), invited us to a dinner, at which there were many excellent speeches. Finally, we were invited to the theatre, where a comedy by Björnson was admirably acted. This play, entitled "Geography and Love," was perhaps chosen to teach men of science that they ought not to become intolerable nuisances to their wives.

On Sunday morning the special train returned to Christiania, somewhat emptied by the departure by sea of some delegates, who were bound for St. Andrews.

It is notoriously difficult to judge of places and institutions in their holiday dress, but I am sure that all the visitors must have carried away an impression of great activity in the study of literature and science on the part both of the professors and students; and what I have written will have shown how great was the hospitality extended to us during this crowded week.

G. H. DARIVIN.

CELEBRATION OF THE FIVE-HUNDREDTH ANNIVERSARY OF THE FOUNDATION OF THE UNIVERSITY OF ST. ANDREWS.

CELEBRATIONS there have been in St. Andrews from very early times, more especially when its ancient chapels and monasteries were in full activity, and still more when its splendid cathedral, the largest and finest in Scotland (yet so ruthlessly destroyed by the Reformers) lent its countenance to the ceremonies. The present, however, surpasses them all save in the absence of the King, who so often favoured the city and the University up to the time of Charles II. Thus, to confine the remarks to academic life, great were the rejoicings on February 14, 1413, when Henry Ogilvie, M.A., the bearer of the papal Bull of the cultured Benedict III. endowing the young University with its important privileges, entered the city. Bells sounded from the steeples, a solemn convocation of the clergy was held in the refectory of the Priory, and a procession to the high altar of the cathedral was made by the whole assembly in rich canonicals, "whilst 400 clerks, besides novices and lay brothers and an immense number of spectators, bowed down before the high altar in gratitude and adoration." 1 After high mass the day was devoted to mirth and festivity. Such was a fitting baptism to a university which owed its beginning more to the impulse of learned men to teach than to public or private endowments. No special buildings at first existed, the masters opening pedagogies in various parts of the town, the larger meetings in churches or in the refectory of the Priory so recently and so judiciously restored by the late Lord Bute.

Now, after the lapse of five centuries of an almost unbroken continuity in academic life, the University again engages in festivity and rejoicing. During its long and chequered career it has surmounted numerous trials and difficulties-such as the turmoil of revo-

$$
1 \text { Tytler, "Hist. Scot." }
$$

No. 2 I86, VOL. 87] 
lutions, the asperities of reformations, and the paralysing spoliations-and to-day is not lacking in vitality, vigour, and eagerness to fit a university of the olden time to every modern improvement. Formerly it had seen the burning of martyrs in front of its gates or in its vicinity, had endorsed the law on the unfortunate witches, and rigidly excluded women even from its quadrangle, on one hand; and, on the other, it had reared or fostered many men of note who spread its fame throughout other lands, or sent its best and wisest to preside over the sister-universities or to teach within their walls. Science, literature, and divinity have been enriched by the labours of its staff throughout this long period, its students have increased in number, women have entered its gates on the same footing as men, and its interests have been widened by the urion with the college of the enterprising and prosperous city of Dundee.

With its long, chequered, and honourable career behind it, and imbued with high purpose for the future, the University held the first function of the celebration on Tuesday afternoon, September 12, in the presentation of his portrait to Mr. Carnegie. This was a gift of the students, Senate, and University Court in recognition of their former rector's munificence to the University, for to him it owes, amongst other things, its fine Carnegie Park, pavilions, library, and gymnasium. The picture represents Dr. Carnegie in his robes as rector. Principal Sir James Donaldson made the presentation on behalf of the subscribers, and Dr. Carnegie made a notable acknowledgment.

In the evening there was a reception by the chancellor, Lord Balfour of Burleigh, who, with Lady Balfour, graciously received the great concourse of visitors and others in the North Hall at the United College of St. Salvator and St. Leonards. No more brilliant scene could have been imagined. Not even the great array of silver ornaments and statues, of gorgeously arrayed Churchmen of every rank at the celebration of the endowment of the young University in I4 I3 to grant degrees by the papal Bull, could have exceeded the varied and striking array of the representatives of science, of medicine, of arts, divinity, law, and other distinguished men and women from almost every civilised country in lines from New Zealand to Australia and radiating through the old world and through the new to the old grey city on the Scottish coast. The bright colours and ornamentation of the robes and hoods, the gold chains of office-academic and civilthe brilliant orders and medals, and the still more varied colours and graceful drapery of the ladies, mingled with the sheen of spurs and the full-dress uniforms of military men, both highland and lowland, of representatives of the navy and groups of civic dignitaries, made a scene never to be forgotten. One thing more only can be alluded to, and it is that the welcome given by Lord and Lady Balfour to every one of the 3500 was of such a kind that from first to last the proceedings were of a most pleasant and harmonious kind. The band of the Scots Guards at the eastern end of the hall enlivened the proceedings, which were further enhanced by the chaste decoration of the interior, from the platform to the opposite end.

Moreover, a torch-light procession of the students starting from the Carnegie Park, clad in the most varied and fantastic costumes, made a striking and most fascinating scene throughout the city, as the long, snake-like line of fire wound its way along crescent, street, and promenade. Whether man or woman held the torch it was sometimes difficult to say; so that if the women students were not present, NO. 2 I 86 , VOL. 87$]$ their places were sympathetically filled. To add to the charm of the proceedings the old tower of the United College of St. Salvator and St. Leonards was outlined each evening at every angle by rows of electric lamps-white, blue, and red.

Finally, a symposium was held in the Volunteer Hall under the auspices of the Students' Representative Council, at which all graduates and students of the University met. Many old friends thus had an opportunity of seeing each other and of contrasting the old régime with the new, and there was no happier assembly during the celebration than this.

Under bright sunshine the morning of Wednesday, September I3, was occupied by marshalling in the United College quadrangle the assembled University Court, Senate, lecturers, graduates-both ordinary and honorary-students, including members of the Officers Training Corps, delegates and distinguished men from the colonies, India, from foreign universities and societies, Lords of Session, sheriffs, the Provost and Town Council, and others to form a procession to the town church (Holy Trinity), so recently and so finely restored under the auspices of Dr. P. M. Playfair. In the church an impressive commemoration service was performed, chapters were read by the chancellor and vice-chancellor, the "Te Deum Laudamus" was sung, and an appropriate and eloquent sermon was given by the Moderator of the General Assembly (Principal Stewart, of St. Mary's College). Prayers were said by Dr. Playfair and the Very Rev. Archibald Henderson, D.D., clerk of the United Free Church, and it is noteworthy that the first prayer was a translation by the late Márquis of Bute, a former rector of the University, of the prayer given in $1_{4} I_{3}$ on the arrival of the papal Bulls establishing the University. The whole tone of the procession and its surroundings and of the service in the Church of the Holy Trinity was in keeping with old academic tradition, and the same feeling pervaded the great assemblage. In no other Scotch city could the combination of past and present render the scene more purely academic.

In the afternoon the presentation of congratulatory addresses took place in the North Hall, the chancellor, rector, and the staff occupying the platform. About 166 addresses were handed in by the distinguished delegates of universities, learned societies, university general councils, town councils, churches, and other important bodies; and as each was as a rule arrayed in official robes, with gold chains and orders, the scene was one of the most interesting in the celebration. As the representatives of each country were announced, the band played a brief but appropriate piece of music. The chancellor (Lord Balfour of Burleigh), after reading. a letter from the King, then delivered an eloquent and masterly address, in which he welcomed the delegates from all parts of the world, alluded to the founders of the University, its cont:nental character, its modern modifications, the effect of its training on the national life, and finally he sketched a picture of the future of the University. Principal Sir James. Donaldson then welcomed the delegates and guests on behalf of the senate.

A delightful entertainment, consisting of historical tableaux connected with the University, was given by the students in the evening. Moreover, students of the 'eighties (1880-a) had a special symposium.

Equally favourable was the weather of Thursday morning, when the rector of the University, the chosen representative of the students, was installed. The popularity of the Earl of Rosebery, who now has held the rectorship in every Scottish university, was sufficient to have filled the vast hall several times over, and, as it was, every available space was packed, 
little short of 4000 people being present. Before the entrance of the procession of the chancellor, rector, principals, senate, and staff in general, the students beguiled the time with songs, and as the procession entered the band played "Gaudeamus Igitur." The president of the Students' Representative Council then intimated the result of the rectorial election; Lord Rosebery took the oath, was robed, amidst the cheers of the students and audience, and then delivered his address, which was marked throughout as the production of a finished orator and man of affairs, as the experience of a man of letters, and as the counsel of a statesman. $\mathrm{He}$ lightly touched on the early history of the University (much of which recent writers have necessarily borrowed from Lyon, biassed though he was, and others), the troubled times following its foundation, the tenacity of its hold on learning (science for the time being forgotten) amidst the vicissitudes of its centuries, and in a fascinating manner drew a picture of the first rector as a Struldbrug of Swift doomed to perpetual life, who, from a point of vantage, surveyed the progress of the University century after century, and, though shocked at and severely critical in regard to many of the changes, concluded by affirming that, after all, substantial advances had been made all along the line. In his final words the rector counselled the students to hold fast to the simple and temperate life, the dogged perseverance, and the pure and high aims of those who had gone before them. Especially did he warn them of the dangers of losing that self-reliance, that frugality, that resolute application to work, and that masterful surmounting of difficulties which have made their countrymen thrive even under neglect, and have won for them the respect of the world. Above all, should they avoid being a "spoon-fed" nation.

After the conclusion of the rectorial address, congratulations from the Senate were conveyed by Principal Stewart to Sir James Donaldson on the completion of his twenty-fifth year of office, and in recognition of the skill and ability with which he had guided the affairs of the University. The principal feelingly replied. Then the graduation ceremony proceeded. The first (about ninety) were those receiving the honorary degree of LL.D., and as each distinguished graduate stepped on the platform to be capped by the chancellor, he or she was cheered by the students and audience; and so with the fourteen men who received the D.D. degree. Amongst those on whom the degree of LL.D. was conferred were many eminent men of science, as mentioned in the last issue of NATURE (p. 374), some of whom had been students in the old university, or had carried out researches in its marine laboratory.

In the afternoon garden-parties on a large scale were given by the mistress and council of St. Leonards' School in their fine grounds, the band of the Scots Guards playing at intervals; whilst another large party was entertained at Mount-Melville, the seat of Mr. J. Younger. Both had endless beautiful and interesting pictures in scenery and landscape gardening, in fine trees and shrubs, to entertain them, especially at Mount-Melville, where arboriculture has long been prominent.

The banquet in the Bell-Pettigrew Museum in the evening was on a large scale, the chair being occupied by the chancellor, and he was supported by the rector and principals, by Lord Reay, Lord Elgin, Lord Stair, Lord Ailsa, Lord Pentland, Lord Kinnoull, Lord Tullibardine, Lord Haddo, Lord Southesk, Lord Kinnaird, Lord Glenconner, Lord Shaw, the principals of Edinburgh, Glasgow, and Aberdeen, Dr. Andrew Carnegie, Mr. Whitelaw Reid, Mr. A. J. Balfour, the No. 2 I 86 , VOL. 87$]$
Maharajah Gaekwar of Baroda, and a long list of distinguished men. After the loyal toast the chancellor declared the museum open, and alluded to the munificent gift of Mrs. Bell-Pettigrew. Speeches were given by the rector, principals, Mr. Balfour, Sir William Turner, Sir Donald Macalister, Lord Reay, Lord Elgin, Lord Pentland, Mr. Munro-Ferguson, President Butler (New York), and many others, and the dinner was throughout of the most agreeable and successful character.

In order to entertain those whom the limited capacities (550) of the hall had of necessity excluded, a ladies" "at home" was held in the large North Hall, under the auspices of the Ladies' Celebration Committee. Lady Balfour, Lady Leconfield, Lady Helen Munro-Ferguson, and the ladies of the executive committee received the guests, who spent a most enjoyable evening. Moreover, a similar reception was held in the Victoria Art Galleries, Dundee, where Lady Baxter of Invereighty and Mrs. Urquhart, the wife of the Lord Provost of Dundee, received the guests, and the evening was spent in the same happy and memorable way.

The close of the quincentenary celebrations occurred on Friday, September I $_{5}$, which was chiefly spent in Dundee in connection with University College (formerly the Baxter College), which is now an integral part of the University of St. Andrews. A special train conveyed the Court, Senate, staff and guests from St. Andrews to Dundee at ro a.m., and all the visitors assembled at University College Library, signed the visitors' book, and proceeded to the gymnasium, where, on behalf of the council of the college, Lord Camperdown gave them a cordial welcome. Remarks were then made by the chancellor and by the rector, who, in a humorous yet suggestive speech, held that universities of the future would always be founded in great centres of population. The buildings, especially the new Carnegie Physics Laboratory, the medical buildings, the engineering laboratory, the college museum of natural history, the various class-rooms, and the city museum, were then inspected, and a tribute paid to the wonderfully complete arrangements for the teaching of medicine, engineering, physics, and other departments.

A luncheon was given by the University in the drillhall, where the guests were received by Lord Provost Urquhart and the magistrates. The chancellor occupied the chair, and many distinguished men supported him, viz. Lord Reay, Lord Rosebery, Lord Camperdown, Lord Stair, Lord Shaw, the principals, senate, and staff of the University, and others. Between 600 and 700 persons were present. The usual toasts were given, and the company broke up about half-past two to proceed to view various large mills in the city, to join the excursions to Glamis, Rossie Priory, and a sail by steamer to Perth-all under most favourable auspices.

Another function was a graduates' and students' dinner in the Bell-Pettigrew Museum at St. Andrews, presided over by the chancellor, at 7.20 p.m. More than 500 were present, and amongst the guests was Sir Dyce Duckworth, who has so frequently visited St. Andrews, and he, in his speech, took his hearers back to the days of Principal Tulloch, on whose grave that afternoon a procession of old graduates and alumni had placed a wreath. The same would have been done if the grave of Sir David Brewster, of world-wide renown, had been in St. Andrews, for the Universitv cherishes the memory of her, and subsequently Edinburgh's, great scientific principal.

Lastly, a students' ball at Io D.m. brought the proceedings to a termination. This was one of the 
brightest and gayest of the social gatherings, under the auspices of the Students' Representative Council and its president, Mr. Dickey. The uniforms of the officers of the warships at present in St. Andrews Bay, the bright robes of the foreign and British graduates, the varied hues of the ladies' attire, and the gowns of the students themselves lent a charming novelty to the picture.

Thus ended the stately celebration of the five-hundredth anniversary of the foundation of St. Andrews University, under the most cheerful of sunny skies, pure (but not "piercing" air), and amidst the unique academic surroundings of the place, which usually, and unfortunately, are wholly absent in those great populous centres where the universities spoken of by the rector will in future be. But the great stretches of pure sand, the expanse of the blue waters of the bay (on which the warships proudly ride), and the long lines of tidal rocks remind us that nowhere within the British dominions can the sciences of geology, botany, and zoology be studied under more inspiring or more favourable auspices than in the little city by "the cold North Sea." Be that as it may, one thing is certain, viz. that both guests and hosts vied with each other in making this celebration one of the most delightful and memorable gatherings it is possible to conceive.

W. C. M.

\section{EDWARD WHYMPER.}

I Edward Whymper, who died suddenly at Chamonix on Saturday last, September I6, we have lost one who was more than a most undaunted and successful climber of mountains. Born on April 27,1840 , the son of an artist and engraver on wood, he was brought up to the work and carried it to great perfection. He went to the Alps on a professional errand in 1860 and began his career as a climber. Next year he made the first ascent of the Pelvoux, and in 1864 vanquished its neighbour, the Ecrins, the highest summit of Dauphiné. Before that he had attacked the Matterhorn. How this was at last conquered, in $\mathrm{r}_{5}$, and of the tragedy of the return, when four lives were lost, it is needless to tell. In I867 he visited Greenland and attempted to penetrate the inland ice. It was a failure, though not from his fault. In 1872 he returned to do some surveying on the coast. In $1879-80$ he undertook his notable journey to the Ecuadorian Andes, during which he successfully ascended ten volcanic mountains, ranging from $I_{5}$, o0o feet to above 20 ,000 feet, most of them hitherto unclimbed, spent a night on the summit of Cotopaxi, and twice reached that of Chimborazo.

In later years Whymper made four or five exploratory expeditions in the Canadian Rockies and Selkirks. But he was more than a successful mountaineer: he was a keen observer of all natural phenomena. His two great and beautifully illustrated books, "Scrambles amongst the Alps" and "Travels amongst the Great Andes of the Equator," contain much of scientific value. $\mathrm{He}$ was a student of glaciers, and a keen critic of those who claimed for them great powers of erosion; a close observer of volcanic and other geological phenomena, and a collector who knew what was worth bringing. While at Disco Bav he obtained a fine series of fossil plants and of Eskimo relics. From the Andes he brought many specimens of rocks and other material, descriptions of which have been published, and himself wrote a paper on the aneroid barometer, besides devising a modification of the mercurial instrument for use on high mountains.

Whymper's latest books, "Chamonix and Mont

$$
\text { NO. } 2 \text { I } 86 \text {, VOL. } 87 \text { ] }
$$

Blanc," published in 1896 , and "Zermatt and the Matterhorn," which appeared in the following year, are admirable of their kind, and have met with great success. He was a fellow of the Royal Society of Edinburgh, had received the Patron's medal of the Royal Geographical Society, and been decorated with the Order of St. Maurice and St. Lazare, besides being an honorary member of foreign geographical societies and Alpine clubs. T. G. BONNEY.

\section{NOTES}

THE Government of the Commonwealth of Australia has promised to contribute $5000 l$. towards the expenses of the Mawson Antarctic Expedition, and the Victorian Government $6000 l$. This amount brings the contributions of the various Australian Governments to the sum of 22,00ol.

THE friends of the late Christian A. Herter have contributed to a memorial fund in recognition of his labours in promoting medical science. The fund, which amounts to $8000 l$., has been confided to the directors of The Journal of Biological Chemistry. The chief aim of the trust is to further the interests of that journal, which was founded by Herter.

According to the Revue Pratique de l'Electricité, a bronze statue has been erected at Poleymeux, in the Rhone Department, France, in memory of Ampère. The inventor is represented standing in an attitude of meditation, the right hand raised to the forehead, the left clenched. On the side is inscribed "La Science," suggestive of the subject of his meditation.

AN International Engineering Exhibition is to be held in April next at Baku, Russia, and will be open for six weeks. The exhibits will comprise internal-combustion engines, air-compressors, electrical apparatus, motor-cars, \&c. Particulars of the prospective arrangements may be obtained from the sole honorary representative in this country-Dr. P. Dvorkovitz, I Broad Street Place, E.C.

DR. R. KARSTEN, lecturer in comparative religion in the University of Helsingfors, has started on an expedition to Gran Chaco and Bolivia for the purpose of making investigations on the sociology and religion of various tribes of natives, some of whom are little known, while others have never been visited. He will be accompanied by his cousin, O. Lindholm.

M. G. Fayet, of the Paris Observatory, has been appointed astronomer at the Nice Observatory, in succession to M. Simonin.

Mr. Marconi has been elected president of the Junior Institution of Engineers in succession to $\mathrm{Sir} \mathrm{J}$. J. Thomson, F.R.S.

Mr. J. J. Nock has been appointed by the Secretary of State for the Colonies, on the recommendation of the Kew authorities, curator of the Hakgala Gardens, Ceylon.

THE meeting of the International Sanitary Conference to revise the provisions of the convention of 1903 for the prevention of the invasion and propagation of plague and cholera, is to take place in Paris on October to next.

$\Lambda$ CONFERENCE of members of the Museums Association and others interested is to take place in the Free Public Museums, Liverpool, on Wednesday, October 18 , the object being to discuss subjects of interest to those concerned in the work of museums.

Prof. Luigi Carnera, hitherto the director of the International Latitude stations at Carloforte and Oncativo, ras 